\title{
TVORBA KONCEPCIE ÚZEMNÉHO ROZVOJA CYKLOTRÁS V KONTEXTE INTEGROV ANÉMU DOPRAVNÉMU SYSTÉMU A PRVKOV CESTOVNÉHO RUCHU
}

\author{
CREATION OF CONCEPT FOR SPATIAL DEVELOPMENT FOR THE CYCLING PATHS \\ IN THE CONTEXT OF INTEGRATED TRANSPORT SYSTEM AND TOURISM
}

Ing. arch. Martin Hépal; Ing. Otto Tokár; Ing. arch. Mária Rajecká

\begin{abstract}
ABSTRAKT
Koncepce územního rozvoje cyklostezek Bratislavského samosprávného kraje ve vztahu k Integrovanému dopravnímu systému a významným bodem cestovního ruchu (dále jen "koncepce rozvoje cyklostezek") představuje dokument, který slouži jako podklad pro plánovaný rozvoj cyklistických tras a Terminálů integrované osobní dopravy v procesu aktualizace územně plánovací dokumentace regionu a dotčených měst a obcí. Koncepce rozvoje cyklostezek se skládá z analytické a návrhové části. Hlavní částí dokumentu je návrh trasování cyklistické dopravy formou samostatných cyklistických komunikací a cyklostezek $\mathrm{k}$ přestupním uzlům Integrovaného dopravního systému a cílům cestovního ruchu, návrh vybavenosti cyklistické dopravy jakož i Terminálů integrované osobní dopravy. Článek představuje koncepci rozvoje cyklostezek se zaměřením na její závěry a zároveň nabízí metodický návod pro vytváření obdobných koncepcí.
\end{abstract}

Klíčová slova: cyklistická doprava, cyklostezka, Integrovaný dopravní systém.

\section{ABSTRACT}

Concept for spatial development for the cycling paths in Bratislava autonomous region in relation to Integrated transport system and significant tourist landmarks (further referred to as 'Developmental concept of cycling paths) presents a document that serves as a foundation for planned development of the cycling paths and Terminals of integrated passenger transport in the process of updating territorial planning of the region as well as included towns and villages. Developmental concept of cycling paths consists of analytical and practical sections. The main part of the document is a proposal for routing of the cycle transportation in the form of independent cycling routes and paths to the transfer nodes of Integrated transport system. Furthermore, the goal of tourism, design of the facilities of the cycling transport as well terminals of the integrated passenger transport. The paper constitutes a concept of development of the cycling paths focusing on its conclusions, while offering a methodological instruction for the creation of similar concepts.

Key words: cycling, cycling paths, Integrated transport system. 


\section{1 ÚVOD}

Cyklistická doprava je pojem, ktorý v sebe zahŕňa hmotné a prevádzkové aspekty viažuce sa na aktívne využivanie bicykla. Pre cyklistu je prioritný bezpečný a rýchly presun do ciela - do zamestnania, do školy, za občianskou vybavenost'ou a to všetko s možnost'ou prestupu na mestskú alebo medzimestskú hromadnú dopravu. Samozrejmost'ou je využitie infraštruktúrnych doplnkov odstavné plochy, požičovne bicyklov a príslušenstva, servis a iné.

Bicykel je ideálny mestský dopravný prostriedok na krátke vzdialenosti (cca 2 až $5 \mathrm{~km}$ ). Na tejto vzdialenosti je $\mathrm{v}$ porovnaní $\mathrm{s}$ inými druhmi dopravy najrýchlejší, pričom čas prepravy je uvažovaná v zmysle „Door to Door“. Bicykel je v meste konkurencieschopný aj z dôvodu, že cyklisti majú výrazne menšie nároky na statickú dopravu v porovnaní s individuálnou automobilovou dopravou (d'alej len IAD). Problémom v našich pomeroch je však skutočnost', že s návrhom potrebnej cyklistickej infraštruktúry zväčša neuvažujú územné plány miest a obcí, čo znemožňuje koncepčné plánovaný rozvoj cyklodopravy.

\section{$1.1 \quad$ Predmet koncepcie}

Predmetom Koncepcie územného rozvoja cyklotrás Bratislavského samosprávneho kraja vo vztahu k Integrovanému dopravnému systému a významným bodom cestovného ruchu (d’alej len „koncepcia rozvoja cyklotrás“) je analýza jestvujúceho stavu cyklistickej infraštruktúry, dostupnosti prestupových uzlov Integrovaného dopravného systému (d’alej len IDS) a významných bodov cestovného ruchu (d’alej len CR). Hlavnou čast'ou koncepcie rozvoja cyklotrás so zameraním na cyklistickú dopravu je návrh vedenia cyklistov na samostatných cyklistických komunikáciách a cyklistických cestičkách k prestupovým uzlom IDS a ciel'om CR.

Riešené územie je vymedzené hranicami Bratislavského kraja, ktorého plocha je $2052,6 \mathrm{~km}^{2}$. Osídlenie Bratislavského kraja pozostáva z hlavného mesta SR - Bratislavy a 72 obcí. Pričom Bratislava pozostáva zo 17 mestských častí [1].

\section{$1.2 \quad$ Ciel' koncepcie}

Hlavným ciel’om koncepcie rozvoja cyklotrás je odlahčenie pretaženej dopravnej infraštruktúry v regióne a to najmä znížením podielu využívania IAD v prospech cyklistickej dopravy. Cyklistická doprava má menšie nároky na parkovanie a nemá negatívny vplyv na životné prostredie a zároveň podporuje zdravší životný štýl.Koncepcia rozvoja cyklotrás chce prispiet' k zvýšeniu podielu cyklistickej dopravy zo súčasných $1,5 \%$ na $10 \%$ do roku 2020 v súlade so základnou víziou Národnej stratégie rozvoja cyklistickej dopravy a cykloturistiky v SR [2].

Ciel'om je integrácia cyklistickej dopravy s ostatnou dopravou (železničnou dopravou, cestnou dopravou, vodnou dopravou, atd'.), pričom by mala byt' zabezpečená maximálna bezpečnost' všetkých účastníkov cestnej premávky, najmä cyklistov, v miestach kde sa cyklistická dopravná siet’ prekrýva $\mathrm{s}$ cestnou siet'ou.

Ďalším ciel’om koncepcia rozvoja cyklotrás je napojenie cyklistickej dopravnej siete na strategické prestupové uzly - Terminály integrovanej osobnej prepravy (d’alej len TIOP) a zastávky mestskej a medzimestskej hromadnej dopravy. Súčasne je ciel'om, aby sa na strategických prestupových uzloch medzimestskej a mestskej hromadnej dopravy budovali záchytné parkoviská typu „Park and Ride“ a „Bike and Ride“.

Súčast'ou koncepcie je aj zabezpečenie dostupnosti významných turistických a rekreačných ciel'ov v Bratislavskom samosprávnom kraji cyklistickou dopravou na krátke i dlhé vzdialenosti. 


\section{ANALYTICKÁ ČASŤ}

Analytická čast' koncepcie rozvoja cyklotrás hodnotí súčasný rozvojový potenciál Bratislavského samosprávneho kraja (d’alej len BSK) v oblasti cyklistickej dopravy. Nosnou zložkou analytickej časti boli výjazdové rokovania a stretnutia s predstavitel'mi miest, obcí a dotknutých organizácii, vykonané prieskumy priamo $\mathrm{v}$ teréne a štúdium východiskových podkladov, pozri Použitá literatúra / Východiskové podklady.

\subsection{Analýza cyklotrás v Bratislavskom samosprávnom kraji}

Bratislavský samosprávny kraj má v súčasnosti okolo $800 \mathrm{~km}$ vyznačených cykloturistických trás, prevažne v lesnom prostredí [3]. Cyklotrasy v zastavanom území sú vo vel'kej miere vedenie po existujúcich frekventovaných komunikáciách cyklopruhmi alebo cyklokoridormi. Obrovský potenciál pre BSK prináša trasovanie medzinárodných trás EuroVelo týmto územím.

EuroVelo je siet' 14-tich dial'kových cykloturistických trás naprieč celou Európe. Ked' bude siet' EuroVelo v roku 2020 kompletne dokončená, bude celková dížka súčtu jej trás vyše 70 tisíc kilometrov. Cez Slovensko prechádzajú tri trasy EuroVelo, pričom územím BSK prechádza EuroVelo 6 a EuroVelo 13 [4].

\subsubsection{EuroVelo 6 - Dunajská cyklocesta}

Trasa spája Atlantik s Čiernym morom. Na Slovensko vstupuje v obci Berg a má dve varianty: pôvodná, ktorá vedie kratšou čast'ou cez slovenské územie do Rajky v Mad’arsku v dížke $23 \mathrm{~km}$ a neskôr schválený druhý variant, ktorý prechádza l’avým brehom Dunaja cez Prístavný most v Bratislave až do Gabčíkova [4].

\subsubsection{EuroVelo 13 - Cesta Železnej opony}

Cesta železnej opony (Iron Curtain Trail) prechádza naším územím v dížke $96 \mathrm{~km}$. Táto cyklotrasa vstupuje na slovenské územie smerom od rakúskych hraníc v prechode Hohenau - Moravský Svätý Ján a vedie cez Devín do Bratislavy, potom cez most Lafranconi k Mostu SNP a Petržalku do Kittsee v Rakúsku. Je vedená zväčša po hrádzach a účelových komunikáciách riek Morava a Dunaj [4].

\subsection{Analýza Terminálov integrovanej osobnej prepravy}

Prestupné miesta - uzly a zastávky, tvoria strategické body dopravnej siete. Uzly a zastávky sú miesta, kde cestujúci môže vstúpit', resp. vystúpit' zo systému hromadnej dopravy. Uzly tvoria zároveň prestupové miesta, kde môže cestujúci zmenit' trasu, použit' nadväzné spojenie, poprípade prestúpit' na inú formu hromadnej dopravy.

Ďalším ciel’om koncepcia rozvoja cyklotrás je napojenie cyklistickej dopravnej siete na strategické prestupové uzly - Terminály integrovanej osobnej prepravy (d’alej len TIOP) a zastávky mestskej a medzimestskej hromadnej dopravy. Ide najmä o napojenie na stanice a zastávky železničnej osobnej prepravy, ktorá je nosným systémom integrovanej dopravy. Súčasne je ciel’om, aby sa na strategických prestupových uzloch medzimestskej a mestskej hromadnej dopravy budovali záchytné parkoviská typu „Park and Ride“, kedy cestujúci prestupuje s formy IAD na mestskú a medzimestskú hromadnú dopravu a záchytné parkoviská typu „Bike and Ride“, kedy cestujúci prestupuje z cyklistickej dopravy na mestskú a medzimestskú hromadnú dopravu. Tieto parkoviská slúžia na krátkodobé i dlhodobé odstavenie dopravného prostriedku. 
Odstavné zariadenia pre bicykle musí spĺñat’ nasledujúce kritériá [5]:

- bezpečné zaistenie bicykla,

- možnost' uzamknutia bicykla,

- l'ahkú identifikovatel'nost',

- bezbariérovost'.

Najbežnejšou formou sú stojany pre bicykle, pričom štandardom by malo byt' ich zastrešenie. V zahraničí sú bežné uzamykatel'né boxy pre jednotlivé bicykle, uzamykatel'né prístrešky, či automatické parkovacie systémy.

\subsection{Analýzy súčasnej dostupnosti vybraných ciel’ov cestovného ruchu}

Cykloturistika je podmnožinou cyklistickej dopravy a výrazne koreluje s cestovným ruchom. Ciel'om koncepcie rozvoja cyklotrás je zabezpečenie dostupnosti turistických a rekreačných cielov v BSK cyklistickou dopravou na krátke i dlhé vzdialenosti. Dobudovaním cyklistických cestičiek k Terminálom integrovanej osobnej prepravy a ich vzájomným prepojením sa posilní dôležitý tento segment cestovného ruchu najmä pre vidiecke oblasti. Je tu predpoklad pre ich rozvoj, zvýšenie zamestnanosti a konkurencieschopnost'.

\section{NÁVRHOVÁ ČASŤ}

Na základe stanovených ciel’ov a výstupov analytickej časti koncepcie rozvoja cyklotrás boli navrhnuté cyklotrasy tak, aby bola dosiahnutá maximálna integrácia cyklistickej dopravy s ostatnou dopravou a to najmä napojením cyklistickej dopravnej siete na strategické prestupové miesta - uzly a zastávky mestskej a medzimestskej hromadnej dopravy a vedením cyklotrás $\mathrm{k}$ oblastiam s vysokou mierou pracovných príležitostí - priemyselné parky, nadnárodné spoločnosti a intenzívne urbanizované mestské prostredie.

Vytvára sa tým predpoklad pre výrazne väčšie využivanie cyklistickej dopravy spojenej s hromadnou osobnou dopravou pri dochádzaní za prácou, vzdelaním, či občianskou vybavenost’ou a zároveň sa zabezpečí dostupnost' turistických a rekreačných ciel'ov v BSK na krátke i dlhé vzdialenosti. Koncepcia rieši segregáciu cyklodopravy od cestnej dopravy.

Niektoré cyklotrasy vedené po pozemných komunikáciách $\mathrm{v}$ intraviláne i extraviláne sa vplyvom výrazného nárastu využívania IAD v posledných desatročiach stali nebezpečnými a z toho dôvodu boli navrhnuté zrušenie značenia.

\subsection{Návrh trasovania cyklistickej dopravy}

Najdôležitejšou čast'ou koncepcie rozvoja cyklotrás bolo vymedzenie bezpečných cyklistických dopravných trás v území, vychádzajúc z existujúcej sídelnej štruktúry, rozvojových centier a hlavných rozvojových smerov v území ako aj navrhovanej koncepcia rozvoja sídelnej štruktúry BSK ukotvenej v Územnom pláne regiónu - BSK (d’alej len ÚPN R BSK) [1], ktorá je založená na týchto princípoch:

- zachovanie historicky vyvinutej osnovy krajiny,

- $\quad$ rozvoj nadregionálnych väzieb vo vzt’ahu k susedným štátom (Rakúsko, Mad’arsko) a krajom na národnej úrovni (Trnavský kraj),

- rozvoj a podpora existujúcich regionálnych rozvojových centier osídlenia (Malacky, Pezinok, Modra, Senec) a rovnomerných podmienok rozvoja ostatných obcí, 
- $\quad$ rozvoj a podpora regionálnych rozvojových pólov mesta Bratislavy v záujme zníženia dostredivých tokov do mesta Bratislavy za prácou a službami.

Vychádzajúc z uvedených princípov bola navrhnutá základná siet’ rozvoja cyklistickej dopravy pozostáva z 10-tich hlavých (kmeňových) cyklistických trás prepájajúcich strategické prestupové uzly, oblasti s vysokou mierou pracovných príležitostí a významné body cestovného ruchu a pridružených (vetvových, podvetvových), ktoré dopínajú hlavnú siet' a prepájajú obce Bratislavského samosprávneho kraja a mestské časti Bratislavy, pozri Tab. 1 a Obr. 1.

\begin{tabular}{|c|c|c|c|c|c|c|c|c|}
\hline \multirow[b]{2}{*}{ Číslo } & \multirow[b]{2}{*}{ Názov } & \multirow[b]{2}{*}{$\begin{array}{l}\text { Počet } \\
\text { trás }\end{array}$} & \multicolumn{2}{|c|}{ Existujúce } & \multicolumn{2}{|c|}{ Navrhované } & \multicolumn{2}{|c|}{ Spolu } \\
\hline & & & $\begin{array}{l}\text { počet } \\
\text { úsekov }\end{array}$ & $\begin{array}{l}\text { dížka } \\
/ \mathrm{m} /\end{array}$ & $\begin{array}{l}\text { počet } \\
\text { úsekov }\end{array}$ & $\begin{array}{l}\text { dížka } \\
/ \mathrm{m} /\end{array}$ & $\begin{array}{l}\text { počet } \\
\text { úsekov }\end{array}$ & $\begin{array}{l}\text { dížka } \\
/ \mathrm{m} /\end{array}$ \\
\hline 1. & Bratislavská & 46 & 41 & 72856 & 62 & 130383 & 103 & 203239 \\
\hline 2. & Vinohradnícka & 10 & 2 & 3432 & 21 & 69620 & 23 & 73052 \\
\hline 3. & Senecká & 13 & 4 & 9943 & 32 & 59683 & 36 & 69626 \\
\hline 4. & Podunajská & 8 & 0 & 0 & 25 & 52915 & 25 & 52915 \\
\hline 5. & Župná & 15 & 0 & 0 & 40 & 80244 & 40 & 80244 \\
\hline 6. & Gidransko-Vištucká & 5 & 0 & 0 & 16 & 39748 & 16 & 39748 \\
\hline 7. & Žitnoostrovná & 7 & 5 & 9627 & 18 & 33830 & 23 & 43458 \\
\hline 8. & Dunajská & 6 & 10 & 23706 & 4 & 9676 & 14 & 33385 \\
\hline 9. & Záhorská & 19 & 14 & 27432 & 49 & 142570 & 63 & 170002 \\
\hline 10. & Malokarpatská & 17 & 10 & 16561 & 33 & 80219 & 43 & 96780 \\
\hline & Spolu & 146 & 86 & 163558 & 300 & 698888 & 386 & 862446 \\
\hline
\end{tabular}

Tab. 1 Dopravné cyklistické trasy

Pri návrhu cyklistických trás sa prihliadalo k možnostiam využívania existujúcej infraštruktúry ako sú účelové komunikácie, pol’né cesty, hrádze vodných tokov a možnostiam trasovania samostatných nemotoristických komunikácií určených pre cyklistov (cyklistická cestička) v pridružených priestoroch dial’nic, rýchlostných ciest a ostatných pozemných komunikácií ako aj trás inžinierskych sieti. Ďalej sa prihliadalo k možnosti využitia existujúcich bezbariérových prechodov (mosty, lávky, podchody). Cyklistické cestičky boli umiestňované i v súbehu navrhovaných komunikácií v zmysle ÚPN R BSK [1]. Pri navrhovaní prvkov cyklistickej infraštruktúry je potrebné vychádzat' z Technických podmienok navrhovania cyklistickej infraštruktúry TP 07/2014 [5], ktoré vydalo Ministerstvo dopravy, výstavby a regionálneho rozvoja SR. Z hl'adiska komplexnosti systému je potrebné navrhovat' $\mathrm{v}$ nižších stupňoch ÚPP a ÚPD ako aj v projektových dokumentáciách vybavenie cyklistických komunikácií a to najmä:

- $\quad$ cyklistické odpočívadlá,

- $\quad$ servisné stanice pre bicykle,

- $\quad$ odstavné zariadenia pre bicykle.

\section{Základná vybavenost’ parkoviska TIOP typu „Bike and Ride“:}

- $\quad$ stojany pre bicykle, pričom štandardom by malo byt' ich zastrešenie,

- $\quad$ bezbariérový prestup na hromadnú dopravu - v podchodoch a nadchodoch vybavený schodiskovými žliabkami, slúžiacimi pre vedenie bicykla. 


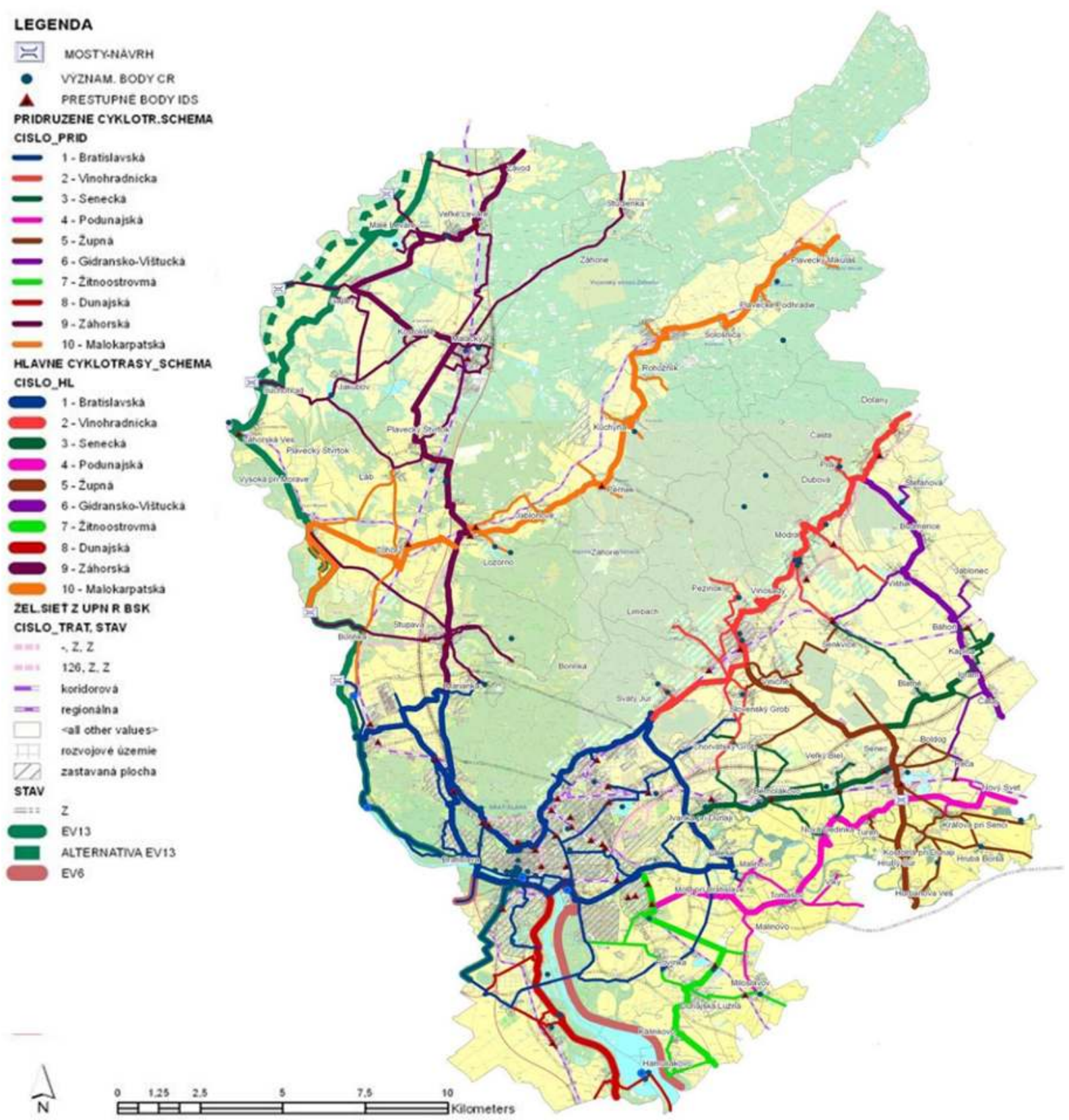

Obr. 1 Návrh trasovania cyklistickej dopravy

\section{ZÁVER}

Koncepcia rozvoja cyklotrás navrhla ucelenú siet' cyklodopravných trás, ako súčast' Integrovaného dopravného systému. Priestorové usporiadanie nových cyklistických cestičiek je potrebné podrobnejšie vymedzit' v nižších stupňoch územnoplánovacej dokumentácie a územnoplánovacích podkladoch a poprípade doplnit' o d’alšie úseky, ktoré neboli riešené v regionálnych súvislostiach, ale na miestnej úrovni majú svoj význam. Cyklistické cestičky navrhujeme zahrnút' medzi stavby verejnoprospešného charakteru.

Koncepcia územného rozvoja cyklotrás Bratislavského samosprávneho kraja vo vzt’ahu $\mathrm{k}$ Integrovanému dopravnému systému a významným bodom cestovného ruchu bola na základe objednávky vypracovaná spoločnost’ou Pozemné stavby TTK s.r.o. Zodpovední riešitelia sú: Ing. Otto Tokár a Ing. arch. Martin Hépal. Obstarávatel’om bol Bratislavský samosprávny kraj. Osoba odborne spôsobilá pre obstarávanie ÚPP a ÚPD: Ing. arch. Mária Rajecká. 


\section{Použitá literatúra}

[1] Územný plán regiónu. Záväzná čast'-Bratislavský samosprávny kraj. [online]. Bratislava, Bratislavský samosprávny kraj, 2013, 37 strán [cit. 20.11.2015]. Dostupné na:

http://www.region-bsk.sk/SCRIPT/ViewFile.aspx?docid=10050878

[2] Národná stratégia rozvoja cyklistickej dopravy a cykloturistiky v Slovenskej republike. [online]. Bratislava, Ministerstva dopravy, výstavby a regionálneho rozvoja Slovenskej republiky, 2015-03, 48 strán [cit. 20.11.2015]. Dostupné na:

http://www.telecom.gov.sk/index/open_file.php?file=doprava/cyklistika/Cyklostrategia_2013 druhe_vydanie_SK.pdf

[3] Územný generel dopravy Bratislavský samosprávneho kraja. Bratislava, Bratislavský samosprávny kraj, 2012-09, 92 strán

[4] EuroVelo na Slovenku. [online]. [cit. 20.11.2015]. Dostupné na:

http://www.eurovelo.sk/sk/; http://www.eurovelo.sk/sk/6; http://www.eurovelo.sk/sk/13

[5] Technické podmienky. Navrhovania cyklistickej infraštruktúry. [online]. Bratislava, Ministerstva dopravy, výstavby a regionálneho rozvoja Slovenskej republiky, 2014-07, 77 strán [cit. 20.11.2015]. Dostupné na:

http://www.telecom.gov.sk/index/open_file.php?file=doprava/dopinfra/cesinfra/tech_predpisy/ 2014/TP_07_2014_navrhovanie_cyklistickej_infrastruktury.pdf 